\title{
Inflammatory myositis in the pediatric rheumatology clinical practice - a case series
}

\author{
S Melo Gomes ${ }^{1 *}$, M Conde ${ }^{2}$, MP Ramos², JA Melo Gomes ${ }^{3}$ \\ From 18th Pediatric Rheumatology European Society (PReS) Congress \\ Bruges, Belgium. 14-18 September 2011
}

\section{Background}

Inflammatory myopathies (IM) in children comprise a heterogeneous group of disorders, the most common being juvenile dermatomyositis and to a lesser degree juvenile polymyositis.

\section{Aim}

To assess the clinical characteristics and treatment response of a cohort of IM patients.

\section{Methods}

Clinical chart review of clinical, laboratory and treatment related parameters of IM patients treated at 2 referral centers for the last 12 years.

Outcome measures included disease remission and muscular function.

\section{Results}

$17 \mathrm{IM}$ patients $(12 \mathrm{~F} / 5 \mathrm{M}$, median age at diagnosis-8years (2-16years)) were followed for a mean of 6,3years (112years): 3 were labeled as polymyositis and 14 as juvenile dermatomyositis.

Positive diagnostic criteria: typical skin lesions-14/17, proximal muscle weakness-15/17, elevated muscle enzymes-16/17, EMG-10/10, muscle biopsy-9/9.

Frequent presenting symptoms included: proximal muscle weakness-16/17, skin lesions-11/17, lethargy-8/ 17, fever-7/17. During follow-up, patients presented with: muscle weakness (17/17), skin lesions (14/17), lipodystrophy (2/17), arthralgia (6/17), arthritis(4/17), vasculitis $(4 / 17)$, gastro-intestinal vasculitis $(1 / 17)$, restrictive pulmonary disease (1/17), calcinosis $(4 / 17)$.

Laboratory: ESR was raised in 6/17, muscle enzymes in 17/17 (CK-16/17, median-1149; LDH 16/17, median-
875; aldolase-7/17); Positive auto-antibodies: ANA-11/ 17, SSA(Ro-52)-2/17; 10/17 underwent muscle biopsy and 9/17 EMG.

Therapeutic regimens included more commonly steroids, methotrexate (17/17) and CyclosporinA (16/17).

Regarding disease activity, 9/17 patients have inactive disease, 6 of which are in remission without treatment; $6 / 17$ have permanent loss of muscular function.

\section{Conclusion}

IM are potentially severe, incapacitating diseases. All patients with polymyositis in this series have loss of muscular function, contrasting with $3 / 14$ of JDM patients.

About half of this cohort is asymptomatic and it should be stressed that early diagnosis and aggressive treatment are important prognostic factors.

\section{Author details}

${ }^{1}$ Department of Pediatrics, Centro Hospitalar Oeste Norte, Portugal. ${ }^{2}$ Department of Pediatrics,Hospital de Dona Estefânia, Portugal. ${ }^{3}$ Pediatric Rheumatology Clinic, Instituto Português de Reumatologia, Lisbon, Portugal.

Published: 14 September 2011

doi:10.1186/1546-0096-9-S1-P59

Cite this article as: Gomes et al.: Inflammatory myositis in the pediatric rheumatology clinical practice - a case series. Pediatric Rheumatology 2011 9(Suppl 1):P59.

* Correspondence: sonia.melo.gomes@gmail.com

${ }^{1}$ Department of Pediatrics, Centro Hospitalar Oeste Norte, Portugal

Full list of author information is available at the end of the article

(c) 2011 Gomes et al; licensee BioMed Central Ltd. This is an open access article distributed under the terms of the Creative Commons Attribution License (http://creativecommons.org/licenses/by/2.0), which permits unrestricted use, distribution, and reproduction in any medium, provided the original work is properly cited. 